Asy-Syari ah: Jurnal Hukum Islam

Vol. 7, No. 2, 2021, Hal.168-186 , ISSN (Print): 2460-3856 ISSN (Online): 2548-5903

DOI: https://doi.org/10.36835/assyariah.v7i2.577

\title{
Positivisasi Perwakafan di Indonesia dalam Sejarah Sistem Hukum Nasional
}

\author{
Nawawi \\ Universitas Ibrahimy Situbondo \\ nawawithabrani71@gmail.com
}

\begin{abstract}
In the history of waqf positivation in Indonesia, there have been ups and downs in accordance with the political and legal policies that have been applied. In the preindependence era of Indonesia, waqf was a tradition of Indonesian society because there were many Islamic kingdoms such as the Demak Kingdom, the Samudera Pasai kingdom, and the Mataram Kingdom. As a consequence, waqf is an inseparable part of Indonesian culture, such as the establishment of mosques, Islamic boarding schools and educational institutions which are sourced from waqf in various parts of the country. Likewise, a strong source of waqf law was born which came from the accumulation of previous books that became the curriculum in Islamic boarding schools. This rule is in the form of Presidential Instruction No. 1 of 1991 concerning Compilation of Islamic Law (KHI). KHI is the result of the agreement of the scholars on marriage, inheritance and waqf which is the main source of reference for judges in the Religious Courts. With the existence of this KHI, the provisions of fiqh that were scattered in various classical fiqh books were automatically unused, because there was already a KHI. KHI is the main source after Government Regulation No. 28 of 1977. If non-binding fiqh changes to qanun, then its status must be followed. Then the position of waqf in the national legal system experiences challenges when referring to the theory of legal pluralism. As a result, legal pluralism in the Indonesian legal system is sometimes strong and weak. However, after the reform era, waqf was experiencing very significant strength. The birth of Law no. 42 of 2004 concerning waqf is more progressive, because it has regulated term waqf (mu'aqqat which accommodates the Hanafiyah mazhab), wakaf of movable objects (money, precious metals, securities, vehicles, intellectual property rights, lease rights, and other movable objects) in accordance with the provisions of shari'ah and applicable laws and regulations) and a more professional Nazhir. In the management of waqf, there have been real actions with pilot projects throughout Indonesia.
\end{abstract}

Keywords: Positivisasi, Waqf, Indonesia

\begin{abstract}
Abstrak
Dalam sejarah positivisasi perwakafan di Indonesia mengalami pasang surut sesuai dengan kebijakan politik dan hukum yang diterapkan. Pada masa pra-kemerdekaan Indonesia, wakaf merupakan tradisi masyarakat Indonesia karena banyak kerajaan Islam seperti Kerajaan Demak, kerajaan Samudera Pasai, dan Kerajaan Mataram. Konsekuensinya, wakaf sebagai bagian yang tidak terpisahkan dari budaya Indonesia, seperti pendirian masjid, pesantren, dan lembaga Pendidikan yang bersumber dari wakaf di berbagai pelosok tanah air. Begitu pula lahir salah satu sumber hukum wakaf yang cukup kuat yang berasal dari akumulasi kitab-kitab terdahulu yang menjadi kurikulum di
\end{abstract}


pesantren. Aturan ini adalah berupa Instruksi Presiden No 1 Tahun 1991 tentang Kompilasi Hukum Islam (KHI). KHI merupakan hasil kesepakatan para ulama tentang perkawinan, kewarisan, dan perwakafan yang menjadi sumber utama rujukan para hakim di Pengadilan Agama. Dengan adanya KHI ini, ketentuan fiqh yang tersebar di berbagai buku fiqh klasik dengan sendirinya tidak terpakai, karena sudah ada KHI. KHI merupakan sumber utama setelah PP No 28 Tahun 1977. Jika fiqh yang bersifat tidak mengikat berubah menjadi qanun, maka statusnya wajib diikutinya. Kemudian posisi perwakafan dalam sistem hukum nasional mengalami tantangan ketika mengacu pada teori pluralisme hukum. Akibtanya, pluralisme hukum dalam sistem hukum Indonesia terkadang kuat dan lemah. Namun, setelah era reformasi perwakafan mengalami kekuatan yang sangat signifikan. Lahirnya UU No. 42 tahun 2004 tentang wakaf adalah lebih progresif, karena telah diatur wakaf berjangka (mu'aqqat yang mengakomodasi mazhab Hanafiyah), wakaf benda bergerak (uang, logam mulia, surat berharga, kendaraan, hak atas kekayaan intelektual, hak sewa, dan benda bergerak lain sesuai dengan ketentuan syari'ah dan peraturan perundang-undangan yang berlaku) dan nazhir yang lebih profesional. Dalam pengelolaan wakaf, telah ada tindakan riil dengan proyek percontohan (pilot project) di seluruh Indonesia.

Kata Kunci: Positivisasi, Perwakafan, Indonesia

\section{A. PENDAHULUAN}

Pada prinsipnya, wakaf mengandung kemaslahatan, dimana investasi bagi wakif sendiri memperoleh pahala dari Allah SWT dan dapat membangun ekonomi umat. Yang paling penting, investasi wakaf sebagai prasarana untuk meningkatkan kualitas kehidupan yang layak dalam aspek ekonomi-sosial. Sangat logis ad-Dahlawi ${ }^{1}$ berpandangan bahwa wakaf mengandung suatu kemaslahatan yang tidak ditemukan dalam sedekah yang lain. Sebab, kadangkala ada orang menggunakan hartanya di jalan Allah, tetapi pada akhirnya habis bendanya. Padahal, masih banyak orang lain yang membutuhkannya. Dengan demikian, tidak ada sedekah yang lebih baik dan bermanfaat bagi orang-orang miskin dan ibnu sabil kecuali harta wakaf yang manfaatnya terus berkembang, sementara bendanya adalah tetap.

Wakaf adalah pusat segala sumber investasi yang meliputi pendidikan, kesehatan, sosial, keamanan, pemikiran, dan kebudayaan. Hal ini dapat dibuktikan dengan adanya warisan-warisan pendahulu kita yang berasal dari wakaf. Dalam kurun waktu yang panjang, wakaf mengalami dinamika, karena adanya faktor internal dan eksternal, tetapi dalam kurun akhir-akhir ini banyak negara melakukan revitalisasi wakaf sebagai modal dan sumber ekonomi bukan hanya negara Islam tetapi juga dari negara Barat.

\footnotetext{
${ }^{1}$ Ad-Dahlawī, 1986, Hujjah Allāh al-Bālighah, Beirūt: Dār al-Fikr, Juz II, h. 116.
} 
Wakaf sebagai sumber ekonomi yang independen, dimana wakif diberi kebebasan untuk mendistribusikan hartanya di jalan Allah SWT. Memang Islam menganjurkan umat Islam agar mengelola hartanya dan mengeluarkannya sebagai infak sesuai dengan ajaran agama Islam. Dalam al-Qur'an, tujuan distribusi ekonomi antara lain terlihat dalam Qs. az-Zariyat (51: 19), kekayaan mereka terdapat hak bagi peminta-minta dan orang yang terhalang. Tujuannya adalah agar harta kekayaan tidak hanya beredar di kalangan orang kaya (Qs. al-Hasyr [59]: 7), ayat tersebut diperkuat oleh Qs. At-Taubah ([9]: 60) bahwa sedekah, baik sedekah wajib maupun sunnah, seperti wakaf ditujukan untuk pemberdayaan dan pengentasan kemiskinan dan prioritas distribusinya terhadap fakir dan miskin. Oleh karena itu, wakaf sebagai bentuk pembelanjaan harta di jalan kebaikan dan sebagai sarana mendekatkan diri kepada Allah.

Wakaf merupakan salah satu bentuk ibadah dan filantropi Islam, nilainya lebih dominan pada ibadah sosial. Ini berarti juga merupakan salah satu jenis dari beberapa jenis ibadah serupa, seperti amal shalih, shadaqah, infak dan lainnya: yang kesemuanya itu merupakan bentuk derma (charity table endowment). Dalam fiqh klasik, pada umumnya wakaf harus mengandung tiga syarat. Pertama, Barang yang diwakafkan adalah barang tetap yang dapat diambil manfaatnya, sehingga tidak seperti mewakafkan makanan yang akan habis setelah dimakan. Kedua, Obyek yang diberi wakaf sudah jelas, bukan yang akan ada, sehingga tidak mungkin menyerahkan harta wakaf kepada orang yang belum lahir, sudah meniggal dunia, dan masjid yang belum ada. Ketiga, Barang yang diwakafkan bukan barang haram. Dengan demikian, tidak dibenarkan mewakafkan tempat perjudian atau tempat lokalisasi pelacuran. ${ }^{2}$

\section{B. PEMBAHASAN}

\section{Perwakafan Sebelum Kemerdekaan RI}

Dinamika praktik yang mirip dengan wakaf telah dilakukan sebelum Islam datang ke Indonesia, seperti 'Huma Serang' di Banten. 'Huma Serang' adalah ladang-ladang yang dikelola setiap tahun secara bersama-sama dan hasilnya digunakan untuk kepentingan bersama. 'Tanah Pareman' di Lombok sebagai tanah negara yang dibebaskan dari pajak landrente dan hasilnya diserahkan pada desa-desa, subak, dan candi untuk kepentingan

\footnotetext{
${ }^{2}$ Azizy, A. Qadri, 2004, Membangun Fondasi Ekonomi Umat, Yogyakarta: Pustaka Pelajar, 112.
} 
bersama. Begitu juga 'Tanah Perdikan' di Jawa Timur, sebuah pemberian raja kepada seseorang atau kelompok yang telah berjasa dan tidak boleh diperjualbelikan. ${ }^{3}$

Wakaf sebagai salah satu lembaga Islam yang berkembang di Indonesia, pada umumnya berupa tanah milik, erat sekali hubungannya dengan pembangunan. Semakin meningkat pembangunan di Indonesia, maka kebutuhan tanah baik untuk memenuhi kebutuhan perumahan perorangan maupun untuk pembangunan prasarana umum seperti jalan, pasar, sekolah, fasilitas olah raga, dan industri terjadi meningkat pula. Kondisi ini dapat menyebabkan masyarakat dan pemerintah mulai memikirkan usahausaha untuk memanfaatkan tanah wakaf secara efisien dan mencegah adanya pemborosan dalam memanfaatkannya. ${ }^{4}$

Rahmat Djatnika ${ }^{5}$ menyatakan praktik wakaf sudah ada sejak kerajaan Islam berkuasa yang menjadi kekuatan politik Islam pada akhir abad ke-12 M. Tradisi yang mirip dengan wakaf di Jawa Timur telah berlaku kira-kira abad ke-15. Hal ini dapat ditelusuri dari peran para Walisongo yang memperkenalkan Islam. Mereka menyebarkan Islam pada lingkungan istana melalui mendirikan pesantren dan masjid di lingkungan kesultanan (istana). Pola ini dilakukan oleh Syekh Maulana Malik Ibrahim (w.1419 M) dan Sunan Ampel (w.1467 M), kemudian jejak mereka diikuti oleh Walisongo yang lain. Masjid dan pesantren sebagai pusat penyebaran Islam dan juga sebagai institusi pertama bagi perkembangan wakaf pada masa berikutnya. ${ }^{6}$ Sementara Azyumardi Azra beranggapan bahwa praktik wakaf pertama kali di Indonesia adalah wakaf konsumtif ketika panetrasi Islam dilakukan oleh para guru sufi ke Nusantara. Peran guru sufi memiliki pengaruh yang besar terhadap penduduk setempat dan memberi andil besar bagi penyebaran Islam. ${ }^{7}$ Dengan demikian, wakaf sebagai kekuatan dan modal utama dalam penyebaran agama Islam di Indonesia. ${ }^{8}$

3 Depag, 2006, Pedoman Pengelolaan dan Pengembangan Wakaf, Jakarta: Direktorat Pemberdayaan Wakaf, 13-14.

${ }^{4}$ Soeprapto, "Perubahan Peruntukan/Penggunaan Tanah Wakaf dari Sudut Agraria", Mimeo, Makalah disampaikan Temu Wicara Perwakafan Tanah Milik, Departemen Agara RI, Jakarta, 19-20 September 1987, 4.

${ }^{5}$ Djatnika, Rahmat, 1962, Wakaf Tanah, Surabaya: Al-Ikhlas, 2021

${ }^{6}$ Najib, Tuti A. (ed.), 2006, Wakaf, Tuhan, dan Agenda Kemanusiaan: Studi Tentang Wakaf dalam Perspektif Keadilan Kemanusiaan di Indonesia, Jakarta: CSRC UIN Jakarta, 73

7 Azra, Azyumardi, 2001, Pendidikan Islam: Tradisi dan Modernisasi Menuju Milenium baru, Juanda: Kalimah, 17.

${ }^{8}$ Hasanah, N., Sulistya, I., \& Irfany, MI (2021). Strategi Pengelolaan Wakaf Uang oleh Badan Wakaf Indonesia (BWI). Al-Awqaf: Jurnal Wakaf Dan Ekonomi Islam , 13 (1), 39. 
Pada masa pra-kemerdekaan Indonesia, wakaf merupakan tradisi masyarakat Indonesia yang mayoritas muslim. Fenomena ini muncul karena banyak kerajaan Islam yang memerintah di nusantara ini. Di antaranya adalah Kerajaan Demak, kerajaan Samudera Pasai, dan Kerajaan Mataram. Hal ini kemudian menjadikan wakaf sebagai bagian yang tidak terpisahkan dari budaya Indonesia. Pendirian masjid, pesantren, dan lembaga pendidikan bersumber dari wakaf sudah populer dilakukan dan dapat dijumpai di berbagai pelosok tanah air. ${ }^{9}$

Wakaf telah diatur oleh hukum adat yang tidak tertulis dan hanya berlandaskan kepada nilai ajaran agama. Meskipun begitu, di era kolonial Belanda, beberapa peraturan wakaf sudah dikeluarkan, di antaranya:

Pertama, Surat Edaran Sekretaris Governemen pertama tanggal 31 Januari 1905, Nomor 435 sebagaimana tertuang dalam Bijblad 1905 No. 6196 tentang Toezicht op den bouw van Muhammadaansche Bedehuizen. Walaupun tidak secara khusus menyangkut wakaf, surat ini menunjukkan bahwa pemerintah Kolonial tidak melarang praktik wakaf yang dilakukan oleh umat Islam demi menjalankan ajaran agamanya. Hanya saja, pembangunan tempat-tempat ibadah itu diperkenankan jika benar-benar diperuntukkan bagi kepentingan umum. Surat Edaran ini berlaku untuk daerah Jawa dan Madura kecuali daerah swapraja. Kepala daerah di kedua wilayah tersebut diizinkan untuk melakukan pendataan dan pendaftaran tanah-tanah atau tempat ibadah umat Islam di daerah masing$\operatorname{masing}^{10}$

Kedua, Surat edaran dari sekretaris Governemen tanggal 4 Juni 1931 Nomor 1361/A yang dimuat dalam Bijblad 1931 Nomor 125/A tentang Toezicht van de regeering op Muhammadaansche Bedehuizen, vrijdagdiensten en wakafs. Surat ini pada prinsipnya menyerukan agar para pemimpin daerah memperhatikan Bijblad 1905 No. 6196 dengan sebaik-baiknya. Bila ada seseorang yang ingin mewakafkan hartanya, ia harus mendapatkan ijin dari Bupati yang akan melakukan penilaian kalayakannya. Jika disetujui, Bupati akan memerintahkan kepada petugas yang ditunjuk untuk memasukkan tanah wakaf itu ke dalam buku khusus di bawah tanggung jawab pengadilan agama. Asisten

9 Djunaidi, Achmad dkk., 2006, Paradigma Baru Wakaf di Indonesia, Jakarta: Direktorat Pemberdayaan Zakat dan Wakaf Depag RI, 14.

10 Abdurrahman, 1979, Masalah Perwakafan Tanah Milik dan Kedudukan Tanah Wakaf di Negara Kita (Bandung: Alumni), 20-21. 
wedana akan mendapat laporan mengenai hal itu untuk kemudian diteruskan ke kantor landrente (pajak).

Ketiga, Surat Edaran sekretaris Governemen tanggal 24 Desember 1934 Nomor 3088/A sebagaimana termuat dalam Bijblad tahun 1934 tahun 1934 No. 13390 tentang Toezicht van de regeering op Muhammadaansche Bedehuizen, vrijdag diensten en wakafs. Surat ini berfungsi sebagai penegas atas surat edaran sebelumnya dan memberikan wewenang sepenuhnya kepada bupati untuk menyelesaikan masalah wakaf jika ada perselisihan atau konflik.

Keempat, Surat Edaran sekretaris Governemen tanggal 27 Mei 1935 Nomor 1273/A sebagaimana termuat dalam Bijblad 1935 Nomor 13480. Surat edaran ini juga memiliki fungsi yang sama, yakni penegasan terhadap surat-surat edaran sebelumnya. Intinya adalah adanya registrasi tanah-tanah wakaf di wilayah Jawa dan Madura. Sebagaimana amanat dari Bijblad 1905 Nomor 6196.

Deskripsi tersebut menunjukkan bahwa praktik wakaf di Indonesia sebelum merdeka mengalami dinamika. Hal ini dapat dilihat dari keberadaan wakaf yang telah diatur oleh hukum adat dan tidak tertulis berdasarkan nilai ajaran agama. Kemudian, pada zaman kolonial telah berkembang dari yang tidak tertulis menjadi tertulis, diantarnya beberapa peraturan wakaf yang telah dikeluarkan oleh pemegang kekuasaan (Belanda), yaitu: Surat Edaran Sekretaris Governemen yang terjadi lima kali, yang mengarah pada pentingnya aturan perwakafan secara tertulis. Dengan demikian, keberadaan wakaf sebelum Indonesia merdeka telah berkembang, sesuai dengan tuntutan zaman.

\section{Perwakafan Pasca Kemerdekaan RI}

Dengan Proklamasi Kemerdekaan RI tanggal 17 Agustus 1945, peraturanperaturan yang dikeluarkan pada masa penjajahan dinyatakan masih berlaku kecuali jika ada aturan baru. Tentu, hal ini logis sesuai dengan pasal peralihan Undang-Undang Dasar 1945. Dalam masalah wakaf, Departemen Agama telah mengeluarkan petunjuk mengenai wakaf, pada tanggal 22 Desember 1953. Dengan demikian, perwakafan dijadikan salah satu wewenang dari Jabatan Urusan Agama, yakni bagian D atau ibadah social.

Surat Edaran Nomor 5/D/1956 tentang Prosedur Perwakafan Tanah dikeluarkan pada tanggal 8 Oktober 1956. Surat ini menindaklanjuti peraturan sebelumnya yang dianggap belum memberikan kepastian hukum di bidang wakaf. Aturan tentang wakaf 
telah dijabarkan lebih lanjut dalam Undang-Undang Nomor 5 Tahun 1960 tentang Agraria. Pasal 49 dapat diketahui ketentuan hukumnya, sebagai berikut: pertama, Untuk keperluan peribadatan dan keperluan suci lainnya sebagai dimaksud dalam pasal 14 dapat diberikan tanah yang dikuasai langsung oleh negara dengan hak pakai. Kedua, Perwakafan tanah milik dilindungi dan diatur dengan peraturan pemerintah.

Pasal ini memberikan penegasan bahwa pemerintah harus memberikan aturan yang sangat jelas tentang wakaf dalam bentuk Peraturan Pemerintah (PP). Namun, PP yang ditunggu-tunggu itu baru lahir 17 tahun kemudian setelah disahkannya Peraturan Pemerintah Nomor 28 Tahun 1977 pada tanggal 17 Mei 1977. Selama rentang waktu tersebut, peraturan yang dipakai adalah peraturan yang telah berlaku sebelumnya. ${ }^{11}$

Beberapa peraturan telah disesuaikan dengan disahkannya PP No 28 Tahun 1977, di antaranya adalah adanya definisi wakaf yang cukup maju:

"Wakaf adalah suatu lembaga keagamaan yang dapat diperuntukkan sebagai salah satu sarana guna pengembangan kehidupan keagamaan, khususnya bagi umat yang beragama Islam dalam rangka mencapai kesejahteraan spiritual dan material menuju masyarakat adil dan makmur berdasarkan Pancasila."

Peraturan yang ada sebelum lahirnya PP ini dianggap belum memenuhi kebutuhan tentang cara-cara perwakafan yang benar dan membuka kemungkinan timbulnya berbagai masalah wakaf. Oleh sebab itu, pemberlakuan PP ini meniscayakan mandegnya peraturan-peraturan sebelumnya, khususnya yang bertentangan dengan PP tersebut. Hal-hal yang belum diatur dalam PP ini akan diatur lebih lanjut oleh Menteri Agama dan Menteri Dalam Negeri sesuai dengan tugas masing-masing. Dengan adanya PP No 28 Tahun 1977, umat Islam mendapat dukungan legal formal dan terperinci mengenai wakaf. PP ini tentu saja berlaku lebih luas tidak hanya wilayah Jawa dan Madura melainkan seluruh wilayah Negara Kesatuan Republik Indonesia. Umat Islam di seluruh penjuru tanah air akan menundukkan diri kepada PP ini.

\section{Perwakafan Pasca Berlakunya PP No 28 Tahun 1977}

Setelah lahirnya PP Nomor 28 Tahun 1977, Indonesia memiliki hukum yang jelas tentang wakaf, terutama wakaf tanah. Departemen Agama melakukan berbagai kegiatan yang mengarah pada PP tersebut, sebagai berikut:

11 Djunaidi, Achmad dkk., 2006, Paradigma Baru Wakaf di Indonesia, Jakarta: Direktorat Pemberdayaan Zakat dan Wakaf Depag RI, 17 
Pertama, Pendataan tanah wakaf hak milik di seluruh pelosok tanah air. Kegiatan ini ditujukan untuk mengetahui jumlah tanah wakaf sehingga memudahkan untuk pengelolaan dan pemberdayaan.

Kedua, Sertifikasi bagi tanah wakaf yang belum mempunyai sertifikat dan bantuan advokasi untuk tanah wakaf yang bersengketa. Hal ini dilakukan karena banyak tanah wakaf yang berpindah tangan sehingga statusnya berubah. Dengan status wakaf yang jelas, perlindungan terhadap tanah wakaf akan lebih mudah. Pihak ahli waris tidak akan begitu saja menjual tanah wakaf orang tuanya karena tanah itu telah memiliki kekuatan hukum (legal-formal).

Ketiga, Upaya pemberdayaan tanah-tanah wakaf secara produktif. Hal ini dilakukan karena umumnya tanah wakaf dikelola secara tradisional. Cara yang dilakukan oleh Departemen Agama adalah menerbitkan buku-buku peraturan perundanganundangan, beragam panduan, dan pedoman praktis sehingga fungsi wakaf menjadi salah satu pilar penyangga perekonomian umat. ${ }^{12}$

Memang sebelum lahirnya UU No. 5 Tahun 1960 dan PP No. 28 Tahun 1977, sebagian masyarakat Indonesia lebih mengandalkan kepercayaan kepada seseorang untuk menerima wakaf, seperti tokoh agama atau kyai untuk dijadikan tempat ibadah dan pendidikan (baca: pondok pesantren). Semenatara, sengketa wakaf sering terjadi disebabkan tidak adanya bukti penyerahan tanah sebagai bentuk wakaf. Dengan lahirnya PP No. 28 Tahun 1977, seseorang yang bermaksud mewakafkan tanahnya, ia harus mengikuti prosedur yang telah ditentukan. Diantaranya adalah adanya keharusan mengikrarkan kehendaknya secara jelas dan tegas kepada nazhir di hadapan Pejabat Pembuat Akta Ikrar Wakaf (PPAIW), yang kemudian ia menuangkan dalam bentuk Akta Ikrar Wakaf dan disaksikan oleh minimal dua orang saksi (pasal 5). Disamping itu juga, syarat orang berwakaf pun sudah ditentukan. Wakif harus berbentuk badan hukum atau orang-orang yang telah dewasa dan sehat akalnya serta oleh hukum tidak terhalang untuk melakukan tindakan hukum, atas kehendak sendiri dan tanpa paksaan dari pihak lain. Begitu pula tanah yang ingin diwakafkan adalah tanah hak milik atau tanah milik yang bebas dari segala pembebanan, ikatan, sitaan, dan perkara (pasal 4). Bagi nazhir, PP ini memberikan persyaratan rinci dan detail.

12 Djunaidi, Achmad dkk., 2006, Paradigma Baru Wakaf di Indonesia, Jakarta: Direktorat Pemberdayaan Zakat dan Wakaf Depag RI, 19-20 
Untuk nazhir perorangan, syaratnya adalah warga negara Indonesia, beragama Islam, sudah dewasa, sehat jasmaniah dan rohaniah, tidak berada di bawah pengampuan, dan bertempat tinggal di kecamatan tempat letaknya tanah yang diwakafkan. Adapun jika berbadan hukum, syarat yang harus dipenuhi adalah badan hukum Indonesia dan berkedudukan di Indonesia dan memiliki perwakilan di kecamatan tempat tanah yang diwakafkan. Nazhir baik perorangan maupun badan hukum harus didaftarkan pada Kantor Urusan Agama (KUA) kecamatan setempat untuk mendapatkan pengesahan.

Secara detail, PP ini mengatur kewajiban dan hak-hak nazhir. Dalam pasal 7 disebutkan bahwa nazhir berkewajiban untuk mengurus dan mengawasi kekayaan wakaf serta hasilnya menurut ketentuan-ketentuan yang diatur lebih lanjut oleh Menteri Agama sesuai dengan tujuan wakaf. Nazhir diwajibkan untuk membuat laporan secara berkala atas semua hal yang menyangkut kekayaan wakaf. Adapun haknya adalah bahwa nazhir berhak mendapatkan penghasilan dan fasilitas yang besarnya dan macamnya ditentukan lebih lanjut oleh Menteri Agama.

Sedangkan tata cara mewakafkan juga diatur dalam PP No. 28 Tahun 1977. Pihak yang bermaksud mewakafkan tanahnya wajib datang di hadapan Pejabat Pembuat Akta Ikrar Wakaf (PPAIW) yang diangkat dan diberhentikan oleh Menteri Agama untuk melaksanakan ikrar wakaf. Tentu suatu keharusan, ikrar itu harus dihadiri oleh paling sedikit dua orang saksi. Surat-surat yang harus dibawa oleh wakif adalah berupa sertifikat hak milik atau tanda bukti pemilikan tanah lainnya, surat keterangan dari kepala desa yang diperkuat oleh Kecamatan setempat yang menerangkan kebenaran pemilikan tanah dan tidak tersangkut sengkata. Surat keterangan pendaftaran tanah, dan izin dari Bupati/Walikota.

Dari deskripsi di atas, jelas bahwa wakaf tanah milik telah diatur secara rinci oleh PP No 28 Tahun 1977. Namun, setelah PP ini disahkan, pemerintah Indonesia masih mengeluarkan berbagai peraturan pelaksanaannya, di antaranya:

a. Peraturan Menteri Dalam Negeri Nomor 6 Tahun 1977 tanggal 26 November 1977 tentang Tata Cara Pendaftaran Tanah Mengenai Perwakafan Tanah Milik.

b. Peraturan Menteri Agama Nomor 1 Tahun 1978 tentang Peraturan Pelaksanaan Peraturan Pemrintah Nomor 28 Tahun 1977. 
c. Peraturan Menteri Dalam Negeri Nomor 12 Tahun 1978 tentang Penambahan Ketentuan Mengenai Biaya Pendaftaran Tanah untuk Badan-Badan Hukum Tertentu pada Peraturan Menteri Dalam Negeri Nomor 2 Tahun 1978.

d. Instruksi Bersama Menteri Agama dan Menteri Dalam Negeri Nomor 1 Tahun 1978 tentang Pelaksanaan Peraturan Pemerintah Nomor 28 Tahun 1977 tentang Perwakafan Tanah Milik.

e. Peraturan Direktur Jenderal Bimbingan Masyarakat Islam Nomor Kep/D/75/78 tentang Formulir dan Pedoman Pelaksanaan Peraturan-Peraturan tentang Perwakafan Tanah Milik.

f. Keputusan Menteri Agama Nomor 73 Tahun 1978 tentang Pendelegasian Wewenang kepada Kepala-kepala Kantor Wilayah Departemen Agama Provinsi/setingkat di seluruh Indonesia untuk mengangkat/memberhentikan setiap kepala Kantor Urusan Agama (KUA) sebagai Pejabat Pembuat Akta Ikrar Wakaf (PPAIW).

g. Instruksi Menteri Agama Nomor 3 Tahun 1979 tentang Petunjuk Pelaksanaan Keputusan Menteri Agama Nomor 73 Tahun 1978.

h. Surat Direktur Jenderal Bimbingan Masyarakat Islam dan Urusan Haji Nomor D.II/5/Ed/14/1980 tentang Pemakaian Bea Materai dengan lampiran surat Dirjen Pajak Nomor S-629/PJ.331/1980 tentang Penentuan Jenis Formulir Wakaf yang Bebas Materai dan yang Tidak Bebas Materai.

i. Surat Dirjen Bimbingan Masyarakat Islam dan Urusan Haji Nomor D.II/5/Ed/11/1981 tentang Petunjuk pemberian Nomor pada Formulir Perwakafan Tanah Milik. ${ }^{13}$

Kemudian, lahir salah satu sumber hukum wakaf yang cukup kuat yang berasal dari akumulasi kitab-kitab terdahulu yang menjadi kurikulum di pesantren. Aturan ini adalah berupa Instruksi Presiden No 1 Tahun 1991 tentang Kompilasi Hukum Islam (KHI). KHI merupakan hasil kesepakatan para ulama tentang perkawinan, kewarisan, dan perwakafan yang menjadi sumber utama rujukan para hakim di Pengadilan Agama. Dengan adanya KHI ini, ketentuan fiqh yang tersebar di berbagai buku fiqh klasik dengan sendirinya tidak terpakai, karena sudah ada KHI. KHI merupakan sumber utama setelah PP No 28 Tahun 1977. Dalam hal ini, fiqh yang bersifat tidak mengikat berubah menjadi qanun yang wajib diikutinya.

\footnotetext{
${ }^{13}$ Mubarok, Jaih, 2008, Wakaf Produktif, Bandung: Simbiosa Rekatama Media, 52.
} 


\section{Perwakafan dalam UU No. 41 Tahun 2004}

Lembaga wakaf sebagai salah satu pilar ekonomi Islam sangat erat kaitannya dengan masalah sosial ekonomi masyarakat. Banyak sekali wakaf dalam suatu negara yang telah berkembang dapat menyelesaikan masalah sosial-ekonomi. Namun, selama ini pemahaman masyarakat Indonesia tehadap wakaf selama berabad-abad sangat terbatas pada wakaf benda tidak bergerak, seperti wakaf tanah. Maka sangat logis, Wael B. Hallaq mengidentikkan wakaf dengan masjid, musalla, dan madrasah. Bahkan sebelum tanggal 27 Oktober 2004, benda wakaf yang diatur dalam peraturan-perundang-undangan hanyalah tanah milik, yakni diatur dalam Peraturan Pemerintah Nomor 28 Tahun 1977 Tentang Perwakafan Tanah Milik. Wakaf benda bergerak khususnya uang baru dibicarakan oleh umat Islam di Indonesia sekitar akhir tahun 2001. Dengan demikian wakaf benda bergerak, terutama wakaf uang belum dikenal secara luas oleh masyarakat. Namun, pada tanggal 11 Mei 2002 Komisi Fatwa Majelis Ulama Indonesia telah menetapkan fatwa tentang wakaf uang, yang isinya, sebagai berikut:

a. Wakaf uang (Cash Waqf/Waqf al-Nuqud) adalah wakaf yang dilakukan seseorang, kelompok orang, lembaga atau badan hukum dalam bentuk uang tunai.

b. Termasuk dalam pengertian uang adalah surat-surat berharga.

c. Wakaf uang hukumnya jawaz (boleh).

d. Wakaf uang hanya boleh disalurkan dan digunakan untuk hal-hal yang dibolehkan secara syar'i.

e. Nilai pokok wakaf uang harus dijamin kelestariannya, tidak boleh dijual, dihibahkan, dan atau diwariskan.

Dalam Undang-undang Wakaf tersebut sudah dimasukkan rumusan konsepsi fiqh wakaf baru di Indonesia yang antara lain meliputi benda yang diwakafkan (mauquf bih); peruntukan wakaf (mauquf 'alaih); sighat wakaf baik untuk benda tidak bergerak maupun benda bergerak seperti uang dan saham; kewajiban dan hak nazhir wakaf; dan lain-lain yang menunjang pengelolaan wakaf produktif.

Dalam Undang-undang Nomor 41 tersebut ada sesuatu yang dapat dibandingkan dengan wakaf yang diatur dalam Peraturan Pemerintah No. 28 Tahun 1977 Tentang Perwakafan Tanah Milik. Dalam Undang-undang tersebut yang diatur tidak hanya perwakafan tanah milik, tetapi juga perwakafan semua benda baik benda bergerak maupun 
benda tidak bergerak, sebagaimana tertuang dalam Pasal 16 ayat (1), harta benda wakaf terdiri:

a. benda tidak bergerak; dan

b. benda bergerak.

Sedangkan dalam ayat (2) disebutkan, benda tidak bergerak sebagaimana dimaksud pada ayat (1) huruf a meliputi:

a. hak atas tanah sesuai dengan ketentuan peraturan perundang-undangan yang berlaku baik yang sudah maupun yang belum terdaftar;

b. bangunan atau bagian bangunan yang berdiri di atas tanah sebagaimana dimaksud pada huruf a;

c. tanaman dan benda lain yang berkaitan dengan tanah;

d. hak milik atas satuan rumah susun sesuai dengan ketentuan peraturan perundangundangan yang berlaku; dan

e. benda tidak bergerak lain sesuai dengan ketentuan syari'ah dan peraturan perundangundangan yang berlaku.

Dalam ayat (3), pasal yang sama disebutkan bahwa benda bergerak sebagaimana dimaksud pada ayat (1) huruf $b$ adalah harta benda yang tidak bisa habis karena dikonsumsi, meliputi:
a. uang;
b. logam mulia;
c. surat berharga;
d. kendaraan;
e. hak atas kekayaan intelektual;
f. hak sewa; dan
g. benda bergerak lain sesuai dengan ketentuan syari'ah dan peraturan perundang- undangan yang berlaku.

Dengan demikian, UU No. 41 tahun 2004 diproyeksikan sebagai sarana rekayasa sosial (social engineering), melakukan perubahan-perubahan pemikiran, sikap dan perilaku umat Islam agar sesuai dengan tujuan UU tersebut. Salah satu regulasi baru dalam Undang-Undang Wakaf tersebut adalah Wakaf Uang. Pengembangan wakaf dalam bentuk 
uang yang dikenal dengan cash wakaf telah dilakukan sejak lama. Bahkan dalam sejarah Islam, wakaf uang telah dipraktikkan sejak abad ke-2 Hijriyah. Imam Bukhari meriwayatkan bahwa Imam al-Zuhri (w. $124 \mathrm{H}$ ), salah seorang ulama terkemuka dan peletak dasar tadwin al-hadits, memberi fatwa boelehnya berwakaf dengan dinar dan dirham, sehingga dapat dimanfaatkan sebagai sarana pembangunan, dakwah, sosial, dan pendidikan umat Islam. Adapun cara yang dilakukan adalah menjadikan uang sebagai modal usaha atau modal produktif, kemudian menyalurkan keuntungannya sebagai wakaf. ${ }^{14}$ Bahkan dalam catatan Abu al-Asybal Syaghif al-Bakistani (tahun 1403) dalam prolog kitab "Risalah fi Jawazi Waqf al-Nuqud" karya Abi Su'ud menyatakan bahwa wakaf uang dinar dan dirham dalam pandangan Imam Syafi'i adalah boleh. Hal ini sama halnya dengan wakaf barang tidak bergerak. Imam Syafi'i sendiri tidak pernah memberi batasan mengenai bentuk dan sifat barang yang diwakafkan. ${ }^{15}$

Dengan demikian, dapat disimpulkan bahwa wakaf di Indonesia setelah era reformasi mengalami dinamika yang sangat signifikan. Yakni, lahirnya UU No. 42 tahun 2004 tentang wakaf adalah lebih progresif, karena telah diatur wakaf berjangka (mu'aqqat yang mengakomodasi mazhab Hanafiyyah), wakaf benda bergerak (uang, logam mulia, surat berharga, kendaraan, hak atas kekayaan intelektual, hak sewa, dan benda bergerak lain sesuai dengan ketentuan syari'ah dan peraturan perundang-undangan yang berlaku), nazhir yang lebih profesional, dan sebagainya.

\section{Perwakafan Pasca UU No. 41 tahun 2004}

Menurut Direktorat Pemberdayaan Wakaf tahun 2012, jumlah aset tanah wakaf di Indonesia seluas 6.018.439.174 M2 yang tersebar di 407.290 lokasi . Aset ini sangat besar sekali bahkan lebih luas jika dibandingkan dengan DKI Jakarta yang luasnya 661,52 KM2 dan Singapura dengan 679 KM2. Hal ini menunjukkan bahwa wakaf memiliki potensi yang besar dalam pengembangan ekonomi. Jika diasumsikan dari jumlah tersebut 10 persen-nya memiliki potensi ekonomi tinggi yang dapat dikelola secara profesionalproduktif, maka aset tanah wakaf di seluruh Indonesia menjadi kekuatan yang signifikan dalam perekonomian bangsa. Potensi inilah yang belum dipahami secara lebih baik bagi pengambil kebijakan perekonomian bangsa. Kekayaan tersebut belum menghitung potensi

\footnotetext{
${ }^{14}$ Muhammad, Abū Su'ūd, 1997, Risālah fi Jawāz. Waqf al-Nuqūd, Beirūt: Ibn Hazm, 20-21.

${ }^{15}$ Abū Su'ūd, 1997, Risālah fī Jawāz Waqf an-Nuqūd, Beirūt: Ibnu Hazm, 12.
} 
wakaf uang yang sedang dan akan terkumpul sebagai salah satu jenis wakaf yang telah diatur dalam peraturan perundang-undangan wakaf. ${ }^{16}$

Dalam sejarah Islam, praktik wakaf telah memberi dampak sosial ekonomi kepada masyarakat yang dipengaruhi oleh ekonomi dan politik. Misalnya, di Turki wakaf uang pernah berkembang dengan pesat, di Mesir wakaf dalam bentuk saham telah dilakukan, serta di Jerusalem banyak wakaf dalam bentuk dapur umum yang memberi makanan kepada fakir miskin. Dua contoh yang terakhir ini adalah tidak pernah dipraktikkan di Indonesia. Hal ini bukan karena perbedaan sumber hukum, tetapi perbedaan interprestasi dan kebutuhan masyarakat. Begitu juga praktik wakaf di Indonesia mengalami transformasi di Indonesia sesuai dengan perkembangan masyarakat. Jika dilihat satu-dua abad belakangan, transformasi ini akan terlihat menonjol. Misalnya, dari abad ke-16 sampai awal abad ke-20, di Indonesia tidak ada inovasi wakaf dalam bentuk sewa ruko atau toko. Wakaf didominasi dalam bentuk tanah, kuburan, sawah, kebun, bangunan sekolah, dan pesantren. Sedangkan saat ini, di Indonesia sudah ada inovasi wakaf uang, wakaf benda-benda bergerak seperti mobil, wakaf rumah sakit, wakaf dalam bentuk usaha toko dan juga bangunan untuk disewakan. Bahkan Departemen Agama dan Badan Wakaf Indonesia mempromosikan wakaf inovatif.

UU No. 41 tahun 2004 telah memiliki pengaruh pada NU secara organisatoris. Pengurus Cabang NU Barito Utara Kalimantan Tengah telah membangun pertokoan dengan dana bantuan awal sebanyak Rp 500.000.000,- dari Depag RI sebagai modal dalam pengembangan wakaf. Pada waktu itu, Ketua Umum PBNU KH. Hasyim Muzadi periode 2004-2009 membuka peletakan batu pertama. Bangunan itu terdiri dari 3 lantai dengan beberapa fasilitas, seperti musalla, penginapan, dan sebagainya. Toko tersebut dijalankan oleh 14 orang yang bertugas dalam bidang kebersihan, keamanan, penjaga toko, dan sebagainya. Keuntungan kegiatan toko itu menjadi sarana peningkatan kesejahteraan masyarakat sekitarnya dalam bentuk santunan rutin yatim piatu, pemberian beasiswa, dan pemberian kredit mikro untuk pengembangan usaha kecil menengah (UKM). ${ }^{17}$

16 Moh. Ahyar Maarif. (2019). Baitul Mal pada Masa Rasulullah Saw dan Khulafaur AlRasyidin. Asy-Syariah : Jurnal Hukum Islam , 5 (2), 139.

17 Depag RI, 2008, Paradigma Baru Wakaf di Indonesia, Jakarta: Direktorat Pemberdayaan Wakaf, 40-41. 
Perkembangan wakaf di Indonesia sangat besar sekali sebagai bentuk kecintaan kemanusian (filantropi). Menurut Azyumardi Azra, umat Islam di Indonesia memiliki potensi besar untuk mewujudkan kedermawanan untuk meringankan beban sebagian masyarakat yang lemah. Bahkan survei menyimpulkan bahwa masyarakat Indonesia lebih dermawan daripada masyarakat Amerika Serikat.

Dalam pengelolaan wakaf perlu adanya tindakan riil melalui proyek percontohan (pilot project). Strategi ini penting, karena jika ada contoh yang sukses, maka pada umumnya masyarakat mengikuti dan berkreasi. Diantara proyek percontohan di seluruh Indonesia dalam pengembangan wakaf produktif setelah lahirnya UU No. 41 tahun 2004 tentang Wakaf, yaitu:

a. Wakaf produktif station pengisian bahan bakar umum (SPBU) di Tangerang

b. Wakaf produktif rumah toko Dar al-Hikam di Cirebon

c. Wakaf produktif satu unit toko dan enam kamar kos muslim di Buleleng Bali

d. Wakaf produktif bisnis center muslimin di kota Pekalongan

e. Wakaf produktif ruang rawat inap vip RSI di Malang

f. Wakaf produktif gedung ruang kegiatan belajar dan penggemukan sapi Konawe di Sulawesi Tenggara

g. Wakaf produktif mini market dan konveksi al-Yasini di Pasuruan

h. Wakaf produktif penggemukan sapi Anwar Makkawi di Rembang

i. Wakaf produktif gedung shopping center di Pekalongan

j. Wakaf produktif toko sembako dan warnet di Jembrana Bali

k. Wakaf produktif mini market Aminah Maros di Sulawesi Selatan

1. Wakaf produktif bisnis center PC NU di Kabupaten Magelang

m. Wakaf produktif swalayan mini Buntet Pesantren di Cirebon

n. Wakaf produktif rumah kost muslim di Buleleng Bali

o. Wakaf produktif gedung balai latihan dan pencerahan qalbu Pangkep di Sulawesi Selatan

p. Wakaf produktif mini market dan restoran Masjid al-Badar di Medan

q. Wakaf produktif pembangunan Toserba Yayasan Badan Wakaf Pondok Modern asSalam Sukabumi di Jawa Barat

r. Wakaf produktif budidaya peternakan sapi di Gresik Jawa Timur 
Praktik wakaf produktif di atas menunjukan bahwa perwakafan di Indonesia telah berkembang dari komsumtif ke produktif atau dari non-profesional ke profesional. Wakaf produktif adalah bentuk pengembangan wakaf yang mendatangkan nilai ekonomis. Hal ini jauh sebelumnya, dimana wakaf identik dengan musalla, madrasah kuburan, dan pondok pesantren. Memang dalam perkembangannya terdapat tiga fase, yaitu fase non-profesional, semi-profesional, dan profesional.

Pertama, fase non-profesional, harta wakaf diperuntukkan hanya untuk pembangunan fisik semata, seperti untuk pekuburan, mesjid, mushalla, dan madrasah. Pada fase ini ikrar wakaf umumnya hanya bersifat lisan tanpa ada bukti tertulis sama sekali. Akibatnya, setelah diurus oleh beberapa generasi banyak harta wakaf yang hilang.

Kedua, fase semi-profesional adalah pengelolaan wakaf sudah mulai dikembangkan secara produktif tetapi belum maksimal. Pelaksanaan wakaf sudah mulai dilakukan secara tertulis dengan melalui Akta Ikarar Wakaf (AIW) yang dibuat oleh Pejabat Pembuat Akta Ikrar Wakaf (PPAIW). Model wakaf ini sudah memiliki kekuatan hukum. Ketiga, fase profesional adalah wakaf dikembangkan secara produktif. Produktif adalah bentuk perwakafan yang dapat mendatangkan nilai ekonomis. Hal dapat dilihat dari UU No. 41 Tahun 2004 dan PP No. 42 Tahun 2006 tentang Wakaf. Dengan demikian, perwakafan di Indonesia telah memasuki pada fase profesional. ${ }^{18}$

Dalam fase ini, pengembangan wakaf secara produktif tidak cukup dengan pengembangan secara tradisional, tetapi perlu melibatkan bank sebagai basis transaksi modern. Memang dalam sejarah, usia perbankan telah dikenal kurang lebih 2500 SM di Mesir Purba dan Yunani Kuno, kemudian baru berkembang di Romawi. Pada umumnya, istilah perbankan dalam masyarakat modern dinamkan bank konvesional. Bank konvensional melaksanakan pembagian keuntungan dengan sistem bunga (persentase) tetap. Konsekuensinya, apakah peminjam mendapat kerugian atau laba.

Berangkat dari hal ini, umat Islam termotivasi untuk mendirikan bank yang berbasis syariah. Di Indonesia, ide pendirian bank syariah telah berkembang sejak tahun 1970. Kajian bank syariah muncul dalam seminar hubungan Indonesia - Timur Tengah pada tahun 1974 dan tahun 1976, yang diselenggarakan oleh Lembaga Studi Ilmu-Ilmu Kemasyarakatan ( LSIK ) dan Yayasan Bhinneka Tunggal Ika. Di tingkat internasional,

${ }^{18}$ Nanang Qosim. (2018). Wakaf Uang dalam Perspektif Hukum Islam. Asy-Syariah : Jurnal Hukum Islam , 4 (1), 56. 
gagasan untuk mendirikan Bank Islam terdapat dalam konferensi Negara-negara Islam di Kuala Lumpur, Malaysia pada tanggal 21 sampai dengan 27 April 1969 yang diikuti 19 negara peserta. Konferensi tersebut menghasilkan beberapa keputusan. Pertama, Tiap keuntungan harus tunduk pada hukum untung dan rugi, jika ia tidak termasuk riba dan riba itu sedikit atau banyak hukumnya haram. Kedua, Diusulkan supaya dibentuk suatu Bank Islam yang bersih dari system riba dalam waktu secepat mungkin. Ketiga, Sementara menunggu berdirinya Bank Islam, bank-bank yang menerapkan bunga diperbolehkan beroperasi. Namun jika benar-benar dalam keadaan darurat. ${ }^{19}$

Dalam konteks ini, ketentuan perbankan yang berkaitan dengan wakaf tertuang dalam SK Dir. BI No.32/34/KEP/DIR tentang Bank Umum Berdasarkan Prinsip Syariah, pasal 29 ayat 2 atau SK Dir. BI No.32/36/KEP/DIR tentang Bank Perkreditan Rakyat Berdasarkan Prinsip Syariah, pasal 28 yang berbunyi: "Bank / BPRS dapat bertindak sebagai lembaga baitul mal yaitu menerima dana yang berasal dari zakat, infak, sedakah, wakaf, hibah atau dana sosial lainnya dan menyalurkannya kepada yang berhak dalam bentuk santunan dan/atau pinjaman kebajikan (qardhul hasan).“ Ketentuan tersebut menyebutkan bahwa bank syariah dapat berperan sebagai penerima dan penyalur dana wakaf.

Disamping itu, bank syariah juga dapat berperan sebagai pengelola dana wakaf, seperti yang tertuang dalam SK Dir. BI No.32/34/KEP/DIR tentang Bank Umum berdasarkan Prinsip Syariah, pasal 28 huruf m atau SK Dir. BI No.32/36/KEP/DIR tentang Bank Perkreditan Rakyat Berdasarkan Prinsip Syariah, pasal 27 huruf c yang berbunyi: "Bank atau BPRS dalam melakukan kegiatan usahanya dapat melakukan kegiatan lain yang lazim dilakukan bank sepanjang disetujui oleh Dewan Syariah Nasional”.

Dengan demikian, pengelolaan wakaf melalui bank merupakan bentuk investasi. Orang yang tidak memanfaatkan hartanya dalam produksi dan menyimpannya tanpa investasi akan kehilangan seperempat dari hartanya dalam waktu kurang dari 12 tahun. Dengan demikian, benda wakaf sebagai sarana membantu orang yang sangat membutuhkan, terutama orang fakir miskin, maka sangat logis bersifat permanen, sehingga selalu mengalir manfaatnya secara terus-menerus. Walaupun manusia memiliki harta, sebenarnya hanya kepemilikan titipan belaka. Sebab, manusia disediakan harta oleh Allah SWT untuk dimiliki bukan untuk disalahgunakan, dibelanjakan bukan dihamburkan,

\footnotetext{
${ }^{19}$ (http://mahjiajie.wordpress.com/2019/07/2).
} 
dikembangkan, dan disimpan. Harta untuk manusia bukan manusia untuk harta. Dalam hal ini, harta sebagai bekal kebaikan dan beramal saleh yang berdimensi sosial, di antaranya mewakafkan harta.

\section{KESIMPULAN}

Berdasarkan paparan di atas dapat disimpulkan bahwa positivisasi hukum wakaf di Indonesia mengalami pasang surut sesuai dengan kebijakan politik dan hukum yang diterapkan. Pada masa pra-kemerdekaan Indonesia, wakaf merupakan tradisi masyarakat Indonesia karena banyak kerajaan Islam seperti Kerajaan Demak, kerajaan Samudera Pasai, dan Kerajaan Mataram. Hal ini kemudian menjadikan wakaf sebagai bagian yang tidak terpisahkan dari budaya Indonesia. Pendirian masjid, pesantren, dan lembaga pendidikan bersumber dari wakaf sudah populer dilakukan dan dapat dijumpai di berbagai pelosok tanah air. Begitu pula lahir salah satu sumber hukum wakaf yang cukup kuat yang berasal dari akumulasi kitab-kitab terdahulu yang menjadi kurikulum di pesantren. Aturan ini adalah berupa Instruksi Presiden No 1 Tahun 1991 tentang Kompilasi Hukum Islam (KHI). KHI merupakan hasil kesepakatan para ulama tentang perkawinan, kewarisan, dan perwakafan yang menjadi sumber utama rujukan para hakim di Pengadilan Agama. Dengan adanya KHI ini, ketentuan fiqh yang tersebar di berbagai buku fiqh klasik dengan sendirinya tidak terpakai, karena sudah ada KHI. KHI merupakan sumber utama setelah PP No 28 Tahun 1977. Dalam hal ini, fiqh yang bersifat tidak mengikat berubah menjadi qanun yang wajib diikutinya.

Dalam konteks ini, posisi hukum perwakafan dalam sistem hukum nasional mengalami tantangan apabila mengacu pada teori pluralisme hukum. Akibtanya, keberadaan pluralisme hukum dalam sistem hukum Indonesia terkadang kuat dan terkadang lemah. Namun, setelah era reformasi perwakafan mengalami kekuatan yang sangat signifikan. Yakni, lahirnya UU No. 42 tahun 2004 tentang wakaf adalah lebih progresif, karena telah diatur wakaf berjangka (mu'aqqat yang mengakomodasi mazhab Hanafiyah), wakaf benda bergerak (uang, logam mulia, surat berharga, kendaraan, hak atas kekayaan intelektual, hak sewa, dan benda bergerak lain sesuai dengan ketentuan syari'ah dan peraturan perundang-undangan yang berlaku) dan nazhir yang lebih profesional. Dalam pengelolaan wakaf, telah ada tindakan riil dengan proyek percontohan (pilot project) di seluruh Indonesia. 


\section{DAFTAR PUSTAKA}

Abdurrahman, 1979, Masalah Perwakafan Tanah Milik dan Kedudukan Tanah Wakaf di Negara Kita (Bandung: Alumni).

Abū Su'ūd, 1997, Risālah fī Jawāz Waqf an-Nuqūd, Beirūt: Ibnu Hazm.

Ad-Dahlawī, 1986, Hujjah Allāh al-Bālighah, Beirūt: Dār al-Fikr.

Azizy, A. Qadri, 2004, Membangun Fondasi Ekonomi Umat, Yogyakarta: Pustaka Pelajar.

Azra, Azyumardi, 2001, Pendidikan Islam: Tradisi dan Modernisasi Menuju Milenium baru, Juanda: Kalimah.

Depag RI, 2008, Paradigma Baru Wakaf di Indonesia, Jakarta: Direktorat Pemberdayaan Wakaf.

Depag, 2006, Pedoman Pengelolaan dan Pengembangan Wakaf, Jakarta: Direktorat Pemberdayaan Wakaf.

Djatnika, Rahmat, 1962, Wakaf Tanah, Surabaya: Al-Ikhlas.

Djunaidi, Achmad dkk., 2006, Paradigma Baru Wakaf di Indonesia, Jakarta: Direktorat Pemberdayaan Zakat dan Wakaf Depag RI.

Hasanah, N., Sulistya, I., \& Irfany, MI (2021). Strategi Pengelolaan Wakaf Uang oleh Badan Wakaf Indonesia (BWI). Al-Awqaf: Jurnal Wakaf Dan Ekonomi Islam, $13(1)$.

Moh. Ahyar Maarif. (2019). Baitul Mal pada Masa Rasulullah Saw dan Khulafaur AlRasyidin. Asy-Syariah : Jurnal Hukum Islam , 5 (2).

Mubarok, Jaih, 2008, Wakaf Produktif, Bandung: Simbiosa Rekatama Media.

Muhammad, Abū Su'ūd, 1997, Risālah fi Jawāz Waqf al-Nuqūd, Beirūt: Ibn Hazm.

Najib, Tuti A. (ed.), 2006, Wakaf, Tuhan, dan Agenda Kemanusiaan: Studi Tentang Wakaf dalam Perspektif Keadilan Kemanusiaan di Indonesia, Jakarta: CSRC UIN Jakarta.

Nanang Qosim. (2018). Wakaf Uang dalam Perspektif Hukum Islam. Asy-Syariah : Jurnal Hukum Islam , 4 (1).

Soeprapto, "Perubahan Peruntukan/Penggunaan Tanah Wakaf dari Sudut Agraria", Mimeo, Makalah disampaikan Temu Wicara Perwakafan Tanah Milik, Departemen Agara RI, Jakarta, 19-20 September 1987. 